\title{
Three Gaseous Neurotransmitters, Nitric oxide, Carbon Monoxide, and Hydrogen Sulfide, Are Involved in the Neurogenic Relaxation Responses of the Porcine Internal Anal Sphincter
}

\author{
Oladayo Folasire, Kylie A Mills, Donna J Sellers, and Russ Chess-Williams* \\ Center for Urology Research, Faculty of Health Sciences and Medicine, Bond University, Gold Coast, Queensland, Australia
}

\section{Background/Aims}

The internal anal sphincter (IAS) plays an important role in maintaining continence and a number of neurotransmitters are known to regulate IAS tone. The aim of this study was to determine the relative importance of the neurotransmitters involved in the relaxant and contractile responses of the porcine IAS.

\section{Methods}

Responses of isolated strips of IAS to electrical field stimulation (EFS) were obtained in the absence and presence of inhibitors of neurotransmitter systems.

\section{Results}

Contractile responses of the sphincter to EFS were unaffected by the muscarinic receptor antagonist, atropine $(1 \mu \mathrm{M})$, but were almost completely abolished by the adrenergic neuron blocker guanethidine $(10 \mu \mathrm{M})$. Contractile responses were also reduced (by $45 \%$ at $5 \mathrm{~Hz}, P<0.01)$ following desensitisation of purinergic receptors with $\alpha, \beta$-methylene-ATP $(10 \mu \mathrm{M})$. In the presence of guanethidine, atropine, and $\alpha, \beta$-methylene-ATP, the remaining relaxatory responses to EFS were examined. These responses were not altered by the cyclooxygenase inhibitor, indomethacin $(5 \mu \mathrm{M})$, the vasoactive intestinal polypeptide receptor antagonist, [o-p-Cl-Phe ${ }^{6}$, Leu ${ }^{17}$ ]vasoactive intestinal peptide (PheLeu-VIP; $100 \mathrm{nM}$ ), or the purinoceptor antagonists, 8-phenyltheophyline (P1 receptors) or suramin

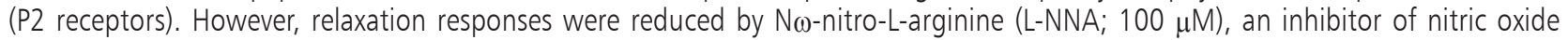
synthesis (40-50\% reduction), zinc protoprophyrin IX $(10 \mu \mathrm{M})$, an inhibitor of carbon monoxide synthesis (20-40\% reduction), and also propargylglycine $(30 \mu \mathrm{M})$ and aminooxyacetic acid $(30 \mu \mathrm{M})$, inhibitors of hydrogen sulphide synthesis (15-20\% reduction).

\section{Conclusions}

Stimulation of IAS efferent nerves releases excitatory and inhibitory neurotransmitters: noradrenaline is the predominant contractile transmitter with a smaller component from ATP, whilst 3 gases mediate relaxation responses to EFS, with the combined contributions being nitric oxide $>$ carbon monoxide $>$ hydrogen sulfide.

(J Neurogastroenterol Motil 2016;22:141-148)

Key Words

Anal canal; Autonomic nerves; Carbon monoxide; Hydrogen sulfide; Nitric oxide

Received: March 2, 2015 Revised: July 14, 2015 Accepted: July 22, 2015

(a) This is an Open Access article distributed under the terms of the Creative Commons Attribution Non-Commercial License (http://creativecommons. org/licenses/by-nc/4.0) which permits unrestricted non-commercial use, distribution, and reproduction in any medium, provided the original work is properly cited.

*Correspondence: Russ Chess-Williams, PhD Center for Urology Research, Faculty of Health Sciences and Medicine, Bond University, University Drive, Gold Coast, Queensland 4229, Australia Tel: +61-7-55954420, E-mail: rchesswi@bond.edu.au 


\section{Introduction}

The internal anal sphincter (IAS) plays an important role in maintaining continence contributing up to $85 \%$ of resting anal tension $^{1}$ and thus it is a potential target for the drug treatment of both anal fissures and fecal incontinence. Fecal incontinence is the uncontrolled passing of fecal material and drugs that increase IAS contractile tone may potentially aid continence, whilst drugs that reduce anal pressure may increase anal blood flow and thereby aid healing of anal fissures.

Both the autonomic and enteric nervous systems influence tone of the IAS. It has been shown histologically that the main autonomic input to the IAS originates in the inferior rectal branches of the pelvic plexus with both tyrosine hydroxylase staining fibers (sympathetic) and nitric oxide (NO) staining fibers (presumed to be parasympathetic) innervating the tissue. ${ }^{2,3}$ In functional experiments, noradrenaline is the only neurotransmitter that has been identified as eliciting an excitatory response in the sphincter, ${ }^{4}$ while inhibitory roles have been suggested for $\mathrm{NO}$, carbon monoxide (CO) and vasoactive intestinal polypeptide (VIP). It has also been suggested that acetylcholine and adenosine 5'-triphosphate (ATP) may also have roles in the relaxation of the sphincter. ${ }^{4}$ Although these neurotransmitters are usually excitatory rather than inhibitory, O'Kelly et $\mathrm{al}^{5}$ has suggested that stimulation of muscarinic receptors by acetylcholine causes the release of $\mathrm{NO}$ and a subsequent relaxation of the IAS.

Previous studies using electrical field stimulation of the IAS have demonstrated the involvement of several neurotransmitters in responses of this tissue. However most of these studies have focused on the relaxation of the sphincter and its relevance to anal fissures, whereas the contractile component, which could be a target for drug development relevant to fecal incontinence, has yet to be explored to the same extent. It is known that NO plays an important role as an inhibitory neurotransmitter in the IAS $^{6}$ and that noradrenaline acting via $\alpha_{1}$-adrenoceptors is responsible for contracting the sphincter. $^{7-9}$ Furthermore, the relative contribution of each neurotransmitter system to the responses of the IAS has not been established. The aim of the present study was to identify the neurotransmitters released during electrical field stimulation (EFS) of the porcine IAS and determine the relative contributions of each transmitter to the functional responses.

\section{Materials and Methods}

Female pig internal anal sphincter (IAS) muscle samples were obtained from a local abattoir. The tissues were immediately placed in Krebs-bicarbonate solution (composition in mmol/L: $\mathrm{NaCl}$ 118.4, $\mathrm{NaHCO}_{3}$ 24.9, $\mathrm{KCl}$ 4.7, $\mathrm{CaCl}_{2}$ 1.9, $\mathrm{MgSO}_{4} 1.15, \mathrm{KH}_{2} \mathrm{PO}_{4}$ 1.15 , and glucose 11.7 ) at $4^{\circ} \mathrm{C}$. The mucosa and submucosa were removed and the circular muscle of the sphincter, approximately $2.5 \mathrm{~cm}$ from the anal opening, was cut into strips $(15 \times 3 \mathrm{~mm})$. The muscle strips were set up in EZ-Bath tissue baths (GlobalTown Microtechnology, Sarasota, FL, USA) containing Krebsbicarbonate solution at $37^{\circ} \mathrm{C}$ and gassed with $5 \% \mathrm{CO}_{2}$ in oxygen. The muscle strips were attached to isometric force transducers connected to a MacLab recording system (AD Instruments Ltd. Bella Vista, NSW Australia) and the developed tension measured using "CHART" software. Tissues were mounted under $1 \mathrm{~g}$ resting tension and allowed to equilibrate for 30 minutes during which time they were washed with fresh Krebs-bicarbonate solution every 15 minutes.

At this point the smooth muscle strips were electrically stimulated (40 $\mathrm{V}$ and 1 millisecond pulse-width) delivered as 5 second trains every 100 seconds, at a frequency of $5 \mathrm{~Hz}$ and then $10 \mathrm{~Hz}$. Initial responses for each frequency were followed by responses in the presence of one of the following drugs which interfere with neurotransmission: $\mathrm{N} \omega$-nitro- $_{\mathrm{L}}$-arginine (L-NNA; $\left.100 \mu \mathrm{M}\right)$, a NO synthase inhibitor; guanethidine $(10 \mu \mathrm{M})$, a neurotoxin selective for adrenergic nerves; atropine $(1 \mu \mathrm{M})$, a muscarinic receptor antagonist; $\alpha, \beta$-methylene-ATP $(10 \mu \mathrm{M})$, a potent purinergic agonist that desensitises $\mathrm{P} 2 \mathrm{X}$ purinoceptors; 1-[p-Chlorobenzoyl]5-methoxy-2-methylindole-3-acetic acid (indomethacin; $5 \mu \mathrm{M}$ ), an inhibitor of cyclooxygenase 1 and 2 (COX 1/2); $1 \mathrm{H}-[1,2,4]$ oxadiazolo[4,3-a] quinoxalin-1-one (ODG; $10 \mu \mathrm{M})$, an inhibitor of guanylate cyclase; and $\left[\mathrm{D}-\mathrm{p}-\mathrm{Cl}-\mathrm{Phe}^{6}{ }^{6} \mathrm{Leu}^{17}\right]$-vasoactive intestinal peptide (PheLeu-VIP; $100 \mathrm{nM}$ ), a vasoactive intestinal polypeptide receptor antagonist. Responses to EFS were repeated in the presence of one of the above antagonists/inhibitors which were equilibrated with tissues for 30 minutes before obtaining responses to EFS. Only one drug was tested on each tissue and control experiments confirmed responses to EFS did not change over this short time period.

\section{Drugs Used}

Atropine (sulfate salt monohydrate), $\alpha, \beta$-methylene ATP (lithium salt), L-NNA, indomethacin, PAG (propargylglycine), 
AOAA (aminooxyacetic acid), methylene blue hydrate, guanethidine, PheLeu-VIP, ODQ, and tetrodotoxin were obtained from Sigma (St. Louis, MO, USA). ZnPPIX (zinc protoporphyrin IX) was obtained from Tocris Bioscience (Ellisville, MO, USA).

\section{Statistical Methods}

Changes in developed tension were represented as a percentage of the tone of the tissue at the time of stimulation and the mean \pm SEM were calculated. The responses seen in the presence of antagonist/inhibitor were compared to the initial responses in the absence of antagonist/inhibitor from the same tissue strip using Student's paired $t$ test. A $P$-value of $\leq 0.05$ was considered statistically significant.

\section{Results}

\section{Influence of Frequency of Stimulation}

The IAS responded to EFS with a relaxation which was followed by a frequency-dependent contraction (Fig. 1). At $5 \mathrm{~Hz}$ stimulation the relaxation was fast, lasting 2-3 seconds, followed by a contraction of approximately 10 seconds duration. Stimulation at a frequency of $10 \mathrm{~Hz}$ produced a contraction that was greatly increased in both size and duration and appeared to mask the relaxation. The responses were neurogenic in origin, and the neurotoxin tetrodotoxin $(3 \mu \mathrm{M}, \mathrm{n}=8)$ completely abolished contractions at both frequencies. Relaxations to EFS were also greatly reduced by tetrodotoxin $(3 \mu \mathrm{M})$ by $78.3 \pm 2.8 \%$ and $91.5 \pm 1.6 \%$ at $5 \mathrm{~Hz}$
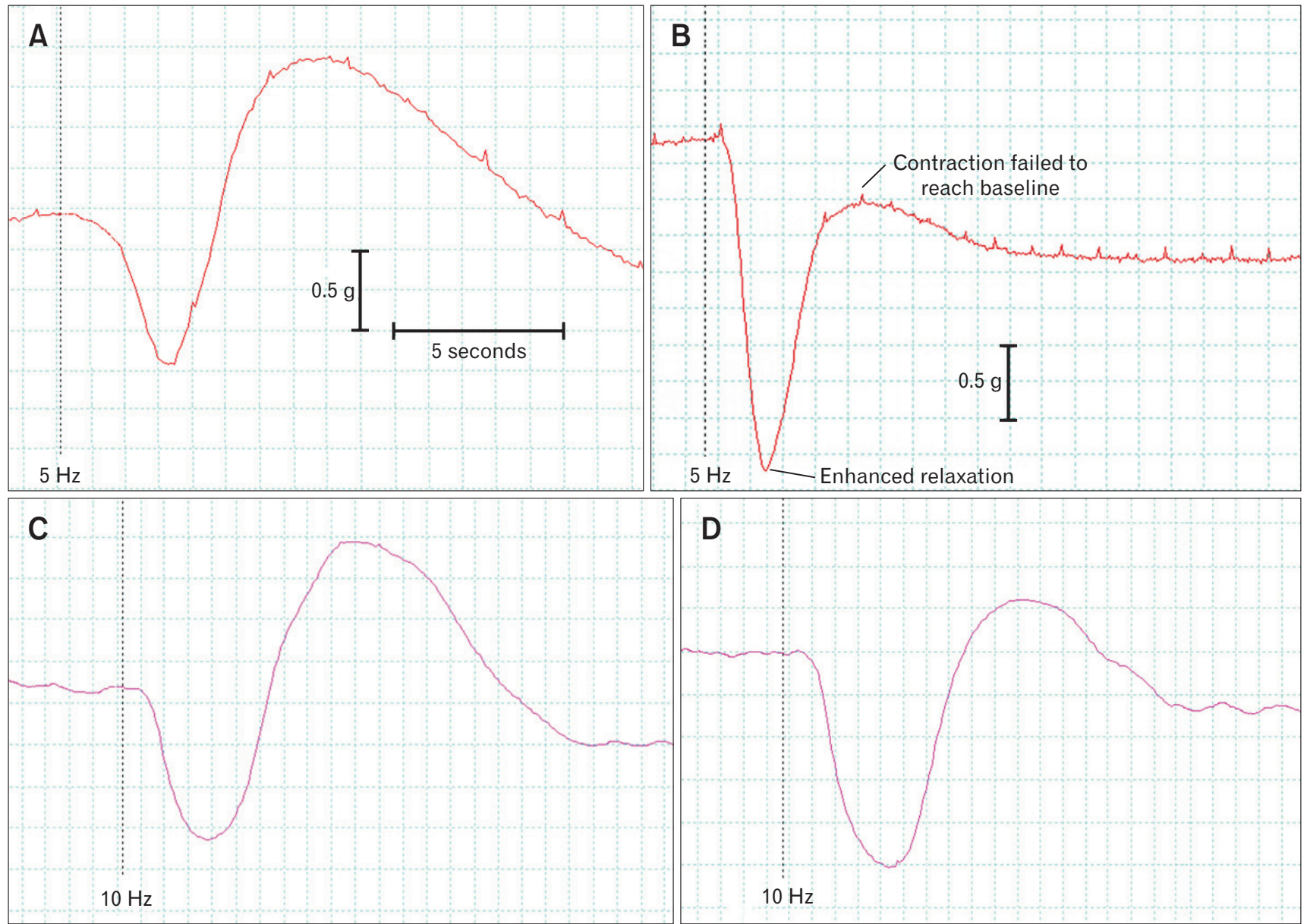

Figure 1. Experimental traces of internal anal sphincter (IAS) responses to electrical field stimulation in the absence and presence of the adrenergic neurone blocker guanethidine $(10 \mu \mathrm{M} ; \mathrm{A}, \mathrm{B})$ before and after desensitisation of $\mathrm{P} 2 \mathrm{X}$ purinergic receptors with $\alpha, \beta-$ methylene-ATP $(10 \mu \mathrm{M}$; C, D). Both drugs reduced contractions and enhanced the relaxations. In the presence of guanethidine, contractions remained below the initial baseline tone. 
and $10 \mathrm{~Hz}$ respectively (both $P<0.001$ ).

\section{Contractile Responses to Electrical Field Stimulation}

Removal of the adrenergic component with guanethidine (10 $\mu \mathrm{M})$ almost completely abolished the contraction of the IAS to electrical stimulation at both frequencies (Table 1). Guanethidine reduced the large contractile responses at $5 \mathrm{~Hz}$ and $10 \mathrm{~Hz}$ to contractions that were superimposed on large relaxations and only recovered to $30 \%$ and $20 \%$ below the baseline respectively (Fig. 1). Contractile responses were also reduced following desensitization of $\mathrm{P} 2 \mathrm{X}$ receptors with the potent purinoceptor agonist $\alpha, \beta$-methyleneATP $(10 \mu \mathrm{M})$. Responses at both frequencies were reduced, but the effect was only statistically significant for responses at $5 \mathrm{~Hz}$ (Table 1). In contrast, responses to electrical stimulation were not significantly altered by the presence of the muscarinic receptor antagonist, atropine $(1 \mu \mathrm{M}$; Table 1$)$.

\section{Relaxation Responses of the Internal Anal Sphincter}

The relaxation responses obtained after removing adrenergic, cholinergic, and purinergic contractions with guanethidine (10 $\mu \mathrm{M})$, atropine $(1 \mu \mathrm{M})$, and a, $\beta$-methylene-ATP $(10 \mu \mathrm{M})$ were also examined in greater detail to determine which inhibitory neurotransmitters were involved and their relative importance. Under these conditions, relaxations to EFS were unaffected by the COX $1 / 2$ inhibitor, indomethacin $(5 \mu \mathrm{M}, \mathrm{n}=14)$ or the VIP-receptor antagonist, PheLeu-VIP (100 nM, $\mathrm{n}=6$; Table 2). However, in the presence of the NO synthase inhibitor L-NNA $(100 \mu \mathrm{M})$, relaxations were reduced by $40-50 \%$ (Fig. 2). Inhibition of guanylate cyclase with ODQ $(10 \mu \mathrm{M})$ produced a greater inhibition than L-NNA, but a combined L-NNA + ODQ treatment did not produce a greater inhibition of relaxation than ODQ alone (Fig. 2).

In another series of experiments the non-nitrergic relaxation remaining in the presence of L-NNA $(100 \mu \mathrm{M})$ was investigated further. As previously, these relaxation experiments were performed in the presence of guanethidine $(10 \mu \mathrm{M})$, atropine $(1 \mu \mathrm{M})$, and a, $\beta$-methylene-ATP $(10 \mu \mathrm{M})$ to remove contractile responses. The relaxations obtained in the additional presence of L-NNA (100 $\mu \mathrm{M})$ were not affected by either the adenosine receptor $(\mathrm{P} 1)$ antagonist 8-phenyltheophyline $(10 \mu \mathrm{M}, \mathrm{n}=5)$ nor the P2-purinoceptor antagonist suramin $(100 \mu \mathrm{M}, \mathrm{n}=5$; data not shown $)$. The

Table 1. Mean ( \pm SEM) Contractions Developed by Tissues in Response to Electrical Field Stimulation.

\begin{tabular}{|c|c|c|c|c|}
\hline \multirow{2}{*}{ Drug/frequency } & & \multicolumn{2}{|c|}{ Contraction ( $\%$ of baseline) } & \multirow{2}{*}{$\begin{array}{c}\text { Inhibition } \\
\text { (\% of control response) }\end{array}$} \\
\hline & & Absence of drug & Presence of drug & \\
\hline \multirow[t]{2}{*}{ Guanethidine $(10 \mu \mathrm{M}, \mathrm{n}=7)$} & $5 \mathrm{~Hz}$ & $21.5 \pm 10.3$ & $-9.0 \pm 4.8^{\mathrm{a}}$ & $130.7 \pm 47.2$ \\
\hline & $10 \mathrm{~Hz}$ & $55.7 \pm 17.3$ & $-8.2 \pm 9.1^{\mathrm{a}}$ & $120.0 \pm 18.7$ \\
\hline \multirow[t]{2}{*}{ Atropine $(1 \mu \mathrm{M}, \mathrm{n}=8)$} & $5 \mathrm{~Hz}$ & $31.1 \pm 6.1$ & $24.7 \pm 7.9$ & $10.0 \pm 20.8$ \\
\hline & $10 \mathrm{~Hz}$ & $46.4 \pm 9.2$ & $35.3 \pm 7.3$ & $13.6 \pm 20.2$ \\
\hline \multirow[t]{2}{*}{$\alpha, \beta$-methylene-ATP $(10 \mu \mathrm{M}, \mathrm{n}=4)$} & $5 \mathrm{~Hz}$ & $33.4 \pm 9.6$ & $19.2 \pm 7.4^{\mathrm{a}}$ & $44.8 \pm 5.0$ \\
\hline & $10 \mathrm{~Hz}$ & $42.5 \pm 6.1$ & $35.0 \pm 7.8$ & $20.4 \pm 15.1$ \\
\hline
\end{tabular}

${ }^{a} P<0.01$ compared to responses in the absence of drug.

Responses are expressed as a percentage of the initial resting tone immediately prior to stimulation. In the presence of guanethidine only relaxation responses were observed (indicated by negative values).

Table 2. Relaxation Responses Expressed As a Percentage of the Tone of the Tissue at the Time of Stimulation.

\begin{tabular}{llccr}
\hline \multirow{2}{*}{ Drug/frequency } & & \multicolumn{2}{c}{ Relaxation (\% of baseline) } & \multicolumn{2}{c}{$\begin{array}{c}\text { Inhibition } \\
\text { (\% of control response) }\end{array}$} \\
\cline { 3 - 4 } L-NNA $(100 \mu \mathrm{M}, \mathrm{n}=26)$ & $5 \mathrm{~Hz}$ & $56.6 \pm 2.2$ & Presence of drug & $42.6 \pm 4.2$ \\
& $10 \mathrm{~Hz}$ & $45.4 \pm 3.7$ & $32.8 \pm 2.8^{\mathrm{a}}$ & $60.4 \pm 4.9$ \\
Indomethacin $(5 \mu \mathrm{M}, \mathrm{n}=14)$ & $5 \mathrm{~Hz}$ & $44.9 \pm 3.7$ & $49.9 \pm 2.9^{\mathrm{a}}$ & $1.7 \pm 2.7$ \\
& $10 \mathrm{~Hz}$ & $47.1 \pm 4.2$ & $44.0 \pm 3.6$ & $4.5 \pm 4.1$ \\
PheLeu-VIP $(100 \mathrm{nM}, \mathrm{n}=6)$ & $5 \mathrm{~Hz}$ & $50.0 \pm 4.2$ & $48.0 \pm 3.9$ & $3.5 \pm 2.5$ \\
& $10 \mathrm{~Hz}$ & $52.6 \pm 4.9$ & $52.0 \pm 4.3$ & $0.7 \pm 2.2$ \\
\hline
\end{tabular}

${ }^{a} P<0.001$ compared to response in the absence of drug.

L-NNA, N $\omega$-nitro-L-arginine; PheLeu-VIP, [D-p-Cl-Phe ${ }^{6}$ Leu $\left.^{17}\right]$-vasoactive intestinal peptide.

An increase in inhibition indicates that the drug did not reduce the relaxation, rather it increased the relaxation. 
A

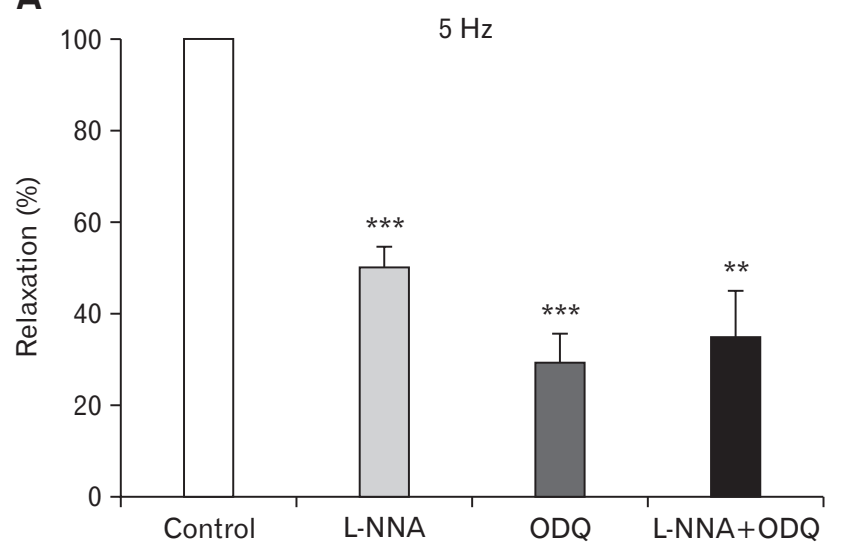

B

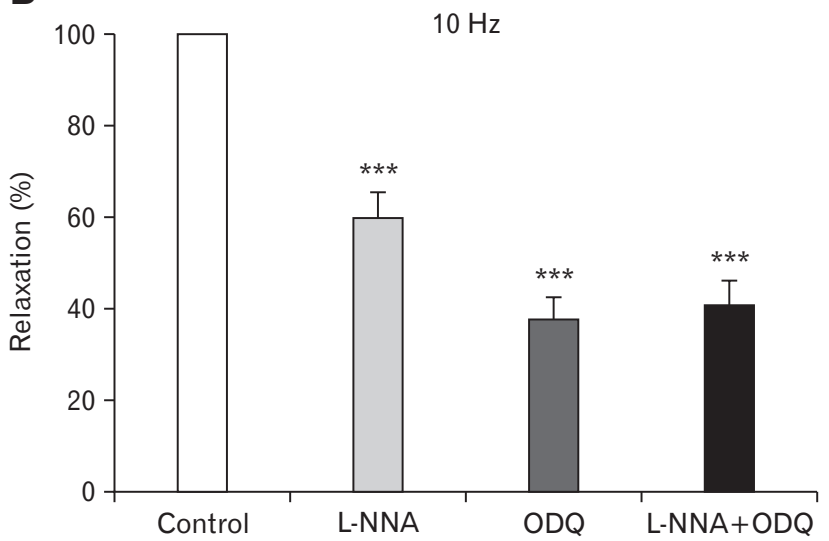

Figure 2. Effects of $\mathrm{N} \omega$-nitro-L-arginine (L-NNA; $100 \mu \mathrm{M})$ and $1 \mathrm{H}$-[1,2,4] oxadiazolo[4,3-a] quinoxalin-1-one (ODQ; $10 \mu \mathrm{M})$, alone and in combination, on the relaxations induced by electrical field stimulation after removal of the adrenergic, cholinergic and purinergic contractile components of responses. Relaxations to electrical field stimulation (EFS) were examined at (A) $5 \mathrm{~Hz}$ and (B) $10 \mathrm{~Hz}$. Mean responses $( \pm \mathrm{SEM}, \mathrm{n}=$ 5-10) are expressed as a percentage of the control pre-drug response to EFS. ${ }^{* *} P<0.01,{ }^{* *} P<0.001$ compared to control values in the absence of inhibitors.
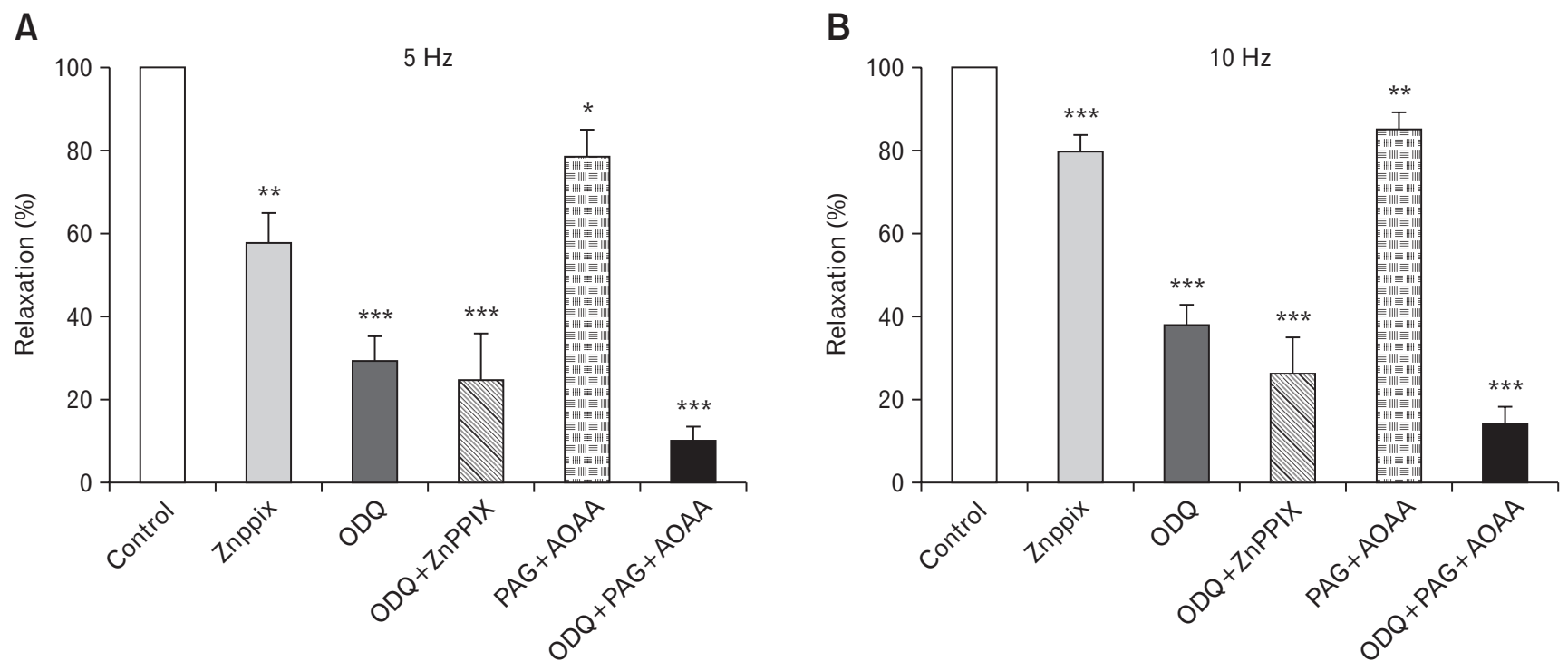

Figure 3. Effects of inhibitors of carbon monoxide (CO) and hydrogen sulfide synthesis on relaxations of the internal anal sphincter. Relaxations to electrical field stimulation (EFS) were examined after removal of the contractile components of responses with guanethidine (10 $\mu \mathrm{M})$, atropine $(1 \mu \mathrm{M})$, and $\alpha, \beta$-mATP $(10 \mu \mathrm{M})$. Responses were obtained at (A) $5 \mathrm{~Hz}$ and (B) $10 \mathrm{~Hz}$ in the absence and presence of the $\mathrm{HO}$ inhibitor zinc protoporphyrin IX $(\mathrm{ZnPPX} ; 10 \mu \mathrm{M})$ and/or inhibitors of the hydrogen sulfide $\left(\mathrm{H}_{2} \mathrm{~S}\right)$ synthesizing enzymes, propargylglycine (PAG; $\left.1 \mathrm{mM}\right)$, and aminooxyacetic acid (AOAA; $30 \mu \mathrm{M})$. Mean responses ( \pm SEM, $\mathrm{n}=5-10$ ) are expressed as a percentage of the control pre-drug response to EFS. ${ }^{* *} P<0.01,{ }^{* *} P<0.001$ compared to control values in the absence of inhibitors of $\mathrm{CO}$ and $\mathrm{H}_{2} \mathrm{~S}$ synthesis.

possible contribution to relaxation by $\mathrm{CO}$ was examined using zinc protoporphyrin IX $(\mathrm{ZnPPIX}, 10 \mu \mathrm{M})$, which inhibits the synthesis of $\mathrm{CO}$ by heme oxygenase, and the contribution to relaxation by hydrogen sulfide $\left(\mathrm{H}_{2} \mathrm{~S}\right)$ was examined using a combination of propargylglycine (PAG, $1 \mathrm{mM}$ ) and aminooxyacetic acid (AOAA, 30 $\mu \mathrm{M})$ to inhibit $\mathrm{H}_{2} \mathrm{~S}$ synthesis. The inhibition of either $\mathrm{CO}$ synthesis or $\mathrm{H}_{2} \mathrm{~S}$ synthesis reduced relaxation to EFS by $20-40 \%$ and $15-$ $20 \%$ respectively (Fig. 3). The inhibition of guanylate cyclase with ODQ reduced relaxations by about $70 \%$ and removing $\mathrm{H}_{2} \mathrm{~S}$ with $\mathrm{PAG}+\mathrm{AOAA}$ further reduced relaxation responses producing 
greater inhibition than ODQ alone. In contrast the effects of CO removal with ZnPPIX were not additive with ODQ, the combination of $\mathrm{ZnPPX}+\mathrm{ODQ}$ yielding the same reduction in relaxation to EFS as ODQ alone (Fig. 3).

\section{Discussion}

In the pig anal sphincter, guanethidine was used to investigate the role of noradrenaline in the contraction of this tissue. Guanethidine is a neurotoxin selective for adrenergic nerves and abolishes adrenergic nerve transmission completely at a concentration of 10 $\mu \mathrm{M} .{ }^{10}$ Guanethidine $(10 \mu \mathrm{M})$ depressed contractions completely from a large contraction above the baseline to one that failed to increase to the baseline level following the initial relaxation response, suggesting a prolonged relaxation mechanism. Thus guanethidine inhibited contraction by $>100 \%$, which prevented an accurate calculation of the contribution of noradrenaline to contraction of the IAS. Although the exact contribution of noradrenaline could not be calculated it can be concluded that noradrenaline is the main excitatory neurotransmitter released in the IAS. In previous studies we have shown that these adrenergic responses are mediated via $\alpha_{1 A / L^{-}}$ adrenoceptors. ${ }^{9}$

In the present study desensitisation of $\mathrm{P} 2 \mathrm{X}$ receptors also depressed responses to EFS indicating an excitatory neurotransmitter role for ATP in this tissue. ATP is often released as a co-transmitter from autonomic nerves and is released with noradrenaline in many tissues including the colon ${ }^{11}$ and vasculature. ${ }^{12}$ These previous studies used the agonist $\alpha, \beta$-methylene-ATP to desensitize P2X purinergic receptors. This potent agonist was used to desensitise the purinergic receptors of the IAS and it depressed contractile responses to EFS, but the inhibition was significantly less than that produced by guanethidine. The reduction of contraction to EFS by $\alpha, \beta$-methylene-ATP was greater at $5 \mathrm{~Hz}$ stimulation than at $10 \mathrm{~Hz}$ suggesting that ATP provides a greater contribution to contractions at lower frequencies of stimulation. Thus the present results suggest a role for ATP in the neurogenic contractions of the anal sphincter via $\mathrm{P} 2 \mathrm{X}$ receptors, at least at lower frequencies of stimulation. Surprisingly, a previous study suggested that ATP is an inhibitory neurotransmitter in the IAS. ${ }^{4}$ In other tissues such as the bladder, ATP is able to induce smooth muscle relaxation via 3 possible mechanisms: (1) directly via P2Y receptors, (2) indirectly by inducing $\mathrm{NO}$ release from epithelial cells, and (3) indirectly via P1 receptors after being broken down to adenosine. ${ }^{13}$ However, in the current studies the mucosa had been removed before tissues were set up and neither the P2-receptor antagonist suramin, nor the P1-receptor antagonist 8-phenyltheophyline had any effect on relaxations, thus ruling out a role for ATP in relaxation responses of this tissue.

After inhibition of the contractile responses, relaxation responses to EFS were greatly enhanced and the mechanisms involved were investigated in more detail. The NO synthase inhibitor LNNA $(100 \mu \mathrm{M})$ reduced the relaxation induced by field stimulation by approximately $40-60 \%$, suggesting that $\mathrm{NO}$ is responsible for approximately half of the relaxation response of the sphincter to nerve stimulation. Also a number of other non-nitrergic inhibitory neurotransmitters have been proposed for the IAS including acetylcholine, VIP, $\mathrm{CO}$, and $\mathrm{H}_{2} \mathrm{~S}$. Previous studies have suggested that muscarinic receptor stimulation results in relaxation which appears to be mediated via the release of $\mathrm{NO} .^{5}$ In the present study muscarinic receptor stimulation with carbachol elicited contractions and no relaxation was observed. Furthermore, atropine had no effect on the excitatory responses to EFS and the inhibitory responses were obtained in the presence of atropine, ruling out a contribution from acetylcholine. In other tissues, such as blood vessels muscarinic receptor stimulation of epithelial cells can release NO to induce relaxation. ${ }^{14}$ Similarly, in the urinary bladder, muscarinic receptors are responsible for direct smooth muscle contraction, ${ }^{15}$ but they may also stimulate release of $\mathrm{NO}$ from urothelial cells. ${ }^{16-18}$ In the present study experiments were performed on muscle strips with the mucosa removed to allow neurotransmission to be examined without the complication of epithelial influences and no relaxation responses were observed.

The non-nitrergic relaxation induced by EFS in the presence of L-NNA was also investigated. Neither the VIP receptor antagonist PheLeu-VIP nor the COX1/2 inhibitor indomethacin significantly reduce the non-nitrergic relaxation ruling out a role for VIP or prostaglandins in relaxation of the pig IAS, a conclusion also reached by Acheson et $\mathrm{al}^{19}$ in the sheep IAS. However the guanylate cyclase inhibitor $\mathrm{ODQ}^{20}$ did have a significant effect, reducing relaxations by approximately $70 \%$. CO, which mediates smooth muscle relaxation responses via cGMP, is an inhibitory neurotransmitter that plays a role in the relaxation of the opossum sphincter. ${ }^{21}$ Using immunocytochemistry in the same animal, the enzyme heme oxygenase $(\mathrm{HO})$, which produces $\mathrm{CO}$, has been found to be present in the myenteric and submucosal neurones of the IAS as well as in the interstitial cells of Cajal (ICCs) found in this tissue. ${ }^{22}$ The non-nitrergic relaxation of the pig IAS to field stimulation was greatly reduced by ODQ which suggests the involvement of CO in the relaxation of this tissue. This was confirmed using ZnPPIX an inhibitor of $\mathrm{HO}$ which is responsible for the synthesis of $\mathrm{CO}$. 
This inhibitor reduced IAS relaxation responses by about $20 \%$ and this effect was not additive with ODQ. These data suggest that the ODQ sensitive component of the relaxation is composed of predominantly $\mathrm{NO}(50 \%)$ but with a smaller contribution from $\mathrm{CO}$ $(20 \%)$.

In the presence ODQ, the remaining small, non-NO, and non-CO relaxation must be mediated via a neurotransmitter that is cGMP independent. It has been shown that the enzymes responsible for the production of $\mathrm{H}_{2} \mathrm{~S}$ are present in the enteric nerves and the myenteric ICCs, ${ }^{23}$ both of which can be found in the IAS. ${ }^{8,24}$ Inhibition of $\mathrm{H}_{2} \mathrm{~S}$ synthesis with $\mathrm{PAG}+\mathrm{AOAA}$ depressed relaxation responses to EFS and the depression was additive to that of ODQ and therefore independent of cGMP indicating a small role for $\mathrm{H}_{2} \mathrm{~S}$ in relaxation of the IAS to EFS.

In conclusion the neurogenic contraction of the porcine IAS can be attributed mainly to noradrenaline and ATP, with both neurotransmitters probably released from adrenergic nerves. The smooth muscle of the IAS responds with contraction to muscarinic receptor stimulation, but neurotransmission, at least in the pig IAS, does not appear to involve acetylcholine. The relaxations of the IAS to electrical stimulation appears to be mediated by the simultaneous release of all 3 gaseous transmitters with relative contributions $\mathrm{NO}$ $>\mathrm{CO}>\mathrm{H}_{2} \mathrm{~S}$. Non-adrenergic non-cholinergic relaxations of the IAS have been shown in other species, with an involvement of $\mathrm{NO}$, $\mathrm{CO}$, and possibly $\mathrm{H}_{2} \mathrm{~S}$. However, this study demonstrates the simultaneous release of all three gaseous neurotransmitters, and their combined contributions, in mediating relaxation of the porcine IAS.

All these transmitters represent possible targets for drug development where enhancing sphincter tone may aid the treatment of fecal incontinence or reductions in IAS tone can aid healing of anal fissures.

\section{Financial support: None.}

\section{Conflicts of interest: None.}

Author contributions: Russ Chess-Williams and Donna J Sellers: conceptualisation and initiation of study; Kylie A Mills, Oladayo Folasire, Russ Chess-Williams, and Donna J Sellers; data generation, data analysis, and data statistics; and Russ ChessWilliams, Donna J Sellers, Oladayo Folasire, and Kylie A Mills: manuscript preparation.

\section{References}

1. Lestar B, Pennickx F, Kerremans R. The composition of anal basal pressure. An in vivo and in vitro study in man. Int J Colorectal Dis 1989;4:118-122.

2. Kinugasa Y, Arakawa T, Murakami G, Fujimiya M, Sugihara K. Nerve supply to the internal anal sphincter differs from that to the distal rectum: an immunohistochemical study of cadavers. Int J Colorectal Dis 2014;29:429-436.

3. Ishiyama G, Hinata N, Kinugasa Y, Murakami G, Fujimiya M. Nerves supplying the internal anal sphincter: an immunohistochemical study using donated elderly cadavers. Surg Radiol Anat 2014; 36:1033-1042.

4. Rattan. S. The internal anal sphincter: regulation of smooth muscle tone and relaxation. Neurogastroenterol Motil 2005;17(suppl 1):50-59.

5. O'Kelly T, Brading A, Mortensen N. Nerve mediated relaxation of the human internal anal sphincter: the role of nitric oxide. Gut 1993;34:689693.

6. Rattan S, Regan RF, Patel CA, De Godoy MA. Nitric oxide not carbon monoxide mediates nonadrenergic noncholinergic relaxation in the murine internal anal sphincter. Gastroenterology 2005;129:1954-1966.

7. Matsufuji H, Yokoyama J. Neural control of the internal anal sphincter motility. J Smooth Muscle Res 2003:39:11-20.

8. Yamato S, Rattan S. Role of alpha adrenoceptors in opossum internal anal sphincter. J Clin Invest 1990;86:424-429.

9. Mills K, Hausman N, Chess-Williams R. Characterization of the alpha1adrenoceptor subtype mediating contractions of the pig internal anal sphincter. Br J Pharmacol 2008;155:110-117.

10. Cobine CA, Fong M, Hamilton R, Keef KD. Species dependent differences in the actions of sympathetic nerves and noradrenaline in the internal anal sphincter. Neurogastroenterol Motil 2007;19:937-945.

11. Venkova K, Krier J. Stimulation of lumbar sympathetic nerves evokes contractions of cat colon circular muscle mediated by ATP and noradrenaline. Br J Pharmacol 1993;110:1260-1270.

12. Racchi H, Irarrázabal MJ, Howard M, Morán S, Zalaquett R, Huidoro-Toro JP. Adenosine 5'-triphosphate and neuropeptide $\mathrm{Y}$ are cotransmitters in conjunction with noradrenaline in the human saphenous vein. Br J Pharmacol 1999;126:1175-1185.

13. Burnstock G. Purinergic signalling in the urinary tract in health and disease. Purinergic signal 2014;10:103-155

14. Khurana S, Chacon I, Xie G, et al. Vasodilatory effects of cholinergic agonists are greatly diminished in aorta from $\mathrm{M}_{3} \mathrm{R}^{-/}$mice. Eur $\mathrm{J}$ Pharmacol 2004;493:127-132.

15. Hedge SS. Muscarinic receptors in the bladder: from basic research to therapeutics. Br J Pharmacol 2006;147(suppl 2):S80-S87.

16. Kullmann FA, Artim D, Beckel J, Barrick S, De Groat WC, Birder LA. Heterogeneity of muscarinic receptor-mediated $\mathrm{Ca}^{2+}$ responses in cultured urothelial cells from rat. Am J Physiol Renal Physiol 2004;294:F971-F981.

17. Hanna-Mitchell AT, Birder LA. New insights into the pharmacology of the bladder. Current Opin Urol 2008;18:347-352.

18. Andersson MC, Tobin G, Giglio D. Cholinergic nitric oxide release from 
the urinary bladder mucosa in cyclophosphamide- induced cystitis of the anaesthetized rat. Br J Pharmacol 2008;153:1438-1444.

19. Acheson A, Rayment S, Eames T, et al. Investigation of the role of adrenergic and non-nitrergic, non-adrenergic neurotransmission in the sheep isolated internal anal sphincter. Neurogastroenterol Motil 2009;21:335345 .

20. Dellabianca A, Sacchi M, Anselmi L, et al. Role of carbon monoxide in electrically induced non-adrenergic, non-cholinergic relaxations in the guinea-pig isolated whole trachea. Br J Pharmacol 2007;150:220-226.

21. Rattan S, Al Haj R, De Godoy MA. Mechanism of internal anal sphinc- ter relaxation by CORM-1, authentic CO, and NANC nerve stimulation. Am J Physiol Gastrointest Liver Physiol 2004;287:G605-G611.

22. Battish R, Cao GY, Lynn RB, Chakder S, Rattan S. Heme oxygenase-2 distribution in anorectum: colocalization with neuronal nitric oxide synthase. Am J Physiol Gastrointest Liver Physiol 2000;278:G148-G155.

23. Schicho R, Krueger D, Zeller F, et al. Hydrogen sulphide is a novel prosecretory neuromodulator in the Guinea-pig and human colon. Gastroenterology 2006;131:1542-1552.

24. Shafik A, El Sibai O, Ahmed I. The identification of specialized pacemaking cells in the anal sphincter. Int J Colorectal Dis 2006;21:453-457. 